двомовні школи протягом того чи іншого проміжку часу для викладання учням загальноосвітніх предметів використовують дві мови у різній пропорційності, залежно від видів двомовних програм, які вони обрали. Вид двомовних програм найчастіше обирають місцеві органи влади залежно від національного складу населення того чи того регіону та їхнього фінансового становища. Нині у більшості шкіл Сполучених Штатів спостерігається тенденція до паралельного розвитку полікультурності й багатомовності, але в деяких штатах країни використовують одномовні програми, скорочують уроки вивчення іноземних мов, намагаючись тим самим зберегти фінансову базу освіти. Отже, дітей, як правило, позбавляють якісної двомовної і загальної освіти.

Отже, найбільш розповсюдженими особливостями змісту двомовних програм середньої школи США можна назвати: 1) спрямованість двомовних програм на забезпечення всіх учнів якісною освітою; 2) використання двох мов у різному співвідношенні для засвоєння учнями змісту немовних загальноосвітніх предметів (найчастіше математики, гуманітарних наук, різних видів мистецтва, фізичної культури), проведення консультацій зі школярами; 3) використання ефективних прийомів і методів навчання, концептуальних засад навчання мов; 4) розвиток високого академічного рівня мовної компетентності учнів в обох мовах; 5) використання двомовними школами декількох підходів до оцінювання двомовних учнів, зокрема оцінювання їхньою рідною мовою, 6) застосування високих академічних стандартів оцінювання за тестовими технологіями щодо всіх учнів, незалежно від їхньої національної приналежності; 7) сприяння паралельному розвитку полікультурності й багатомовності у двомовних школах тощо.

Використання двомовного навчання є однією з провідних тенденцій розвитку змісту освіти шкіл США в останній третині XX ст. Запровадження у зміст освіти двомовних програм розглядається як засіб підвищення шкільної успішності, розвитку рідної мови, часто перехідний етап до навчання англійською мовою, умова підвищення соціального статусу учнів, реалізація їхніх прав, основа для полікультурного розвитку учнів.

\title{
Література
}

1. Bilingual education in the USA. - [Електронний ресурс]. - Режим доступу: www.youtube.com/watch? $=88 \mathrm{vxOj} 8 \mathrm{CgKU}$. 2. Malarz L. Bilingual Education: Effective Programming for Language-Minority Students. [Електронний pecypc] / L. Malarz. - Режим доступу: http://www.ascd.org/publications/curriculum_handbook/413/chapters/Bilingual_Education@

Effective_Programming_for_Language-Minority_Students.aspx 3. New world Ecyclopedia. - [Електронний peсурс]. - Режим доступу: http: //www. nev. world ecyclopedia.org/ entry/ Bilingual_education. 4. New York State Teacher Certification Examinations. - [Електронний pecypc].Режим доступу: http: //www.nystce.nesinc.com /PDFs/NY_fld028_prepguide. pdf 5. Raising bilingual children. - [Електронний pecypc]. - Режим доступу: http://www.raising-bilingualchildren.com/basics/language-stimulation/bilingual-schools/usa/ 6. Requirements for the Education of Language Minority Children. - [Електронний pecypc]. - Режим доступу: http://www.users.interport.net/r/e /readinst/50state.html 7. San Miguel Guadalupe. Contested Policy: The Rise and Fall of Federal Bilingual Education in the United States, 1960-2001 / Guadalupe San Miguel. - College Station, TX, USA: University of North Texas Press, 2004. - 168 p. 8. Successful Bilingual Education Programs. - [Електронний ресурс]. Режим доступу: http://www.idra.org/IDRA_Newsletter/January_2002_Self_ Renewing_Schools Leadership/Successful_Bilingual_Education_Programs/ 9. The German-American International School (GAIS). - [Електронний ресурс]. - Режим доступу: http://www.gais.org/

\section{ЗАСАДНИЧІ ПРИНЦИПИ ІСНУВАННЯ КИЇВСЬКОГО НАВЧАЛЬНОГО ОКРУГУ В ПЕРІОД 1833-1834 рр. УКАЗИ ІМПЕРАТОРА ТА ЦИРКУЛЯРИ МІНІСТРА НАРОДНОЇ ОСВІТИ (за матеріалами «Журнала министерства народного просвещения»)}

Кільова Г. О. Засадничі принципи існування Київського навчального округу в період 18331834 рр. Укази імператора та циркуляри міністра народної освіти (за матеріалами «Журнала министерства народного просвещения»).

У статті розглянуто функціонування Київського навчального округу і найважливіші державні документи, що визначають його устрій. До них належать укази імператора, 
розпорядження міністра народної освіти, циркуляри попечителя Київського навчального округу. Основну увагу зосереджено на перших двох як таких, що формували принципи роботи навчального округу, визначали головні критерії його розвитку.

Ключові слова: Міністерство народної освіти, навчальний округ, указ, циркуляр, попечитель.

В статье изучено функционирование Киевского учебного округа и самые актуальные в этом плане государственные документы, которые определяют его строй. К ним относятся указы императора, распоряжения министра народного образования, циркуляры попечителя Киевского учебного округа. Основное внимание сосредоточено на первых двух как таких, которые формировали принципы работы учебного округа, определяли главные критерии его развития.

Ключевые слова: Министерство народного образования, учебный округ, указ, циркуляр, попечитель.

Kilyova G. O. Fundamental principles of the Kyiv School District existence during the period of 1833-1834. Decrees of the Emperor and Circulars of the Minister of Public Education (based on the «Journal of the Ministry of National enlightenment»).

The article considers the functioning of the Kiev school district and most relevant government documents in this regard that define its system. These include the decrees of the emperor, the orders of the Minister of Public Education, circulars of Kiev school district trustee. The main focus is on the first two ones, that formed the principles of the school district, determined the main criteria of its development.

Key words: the Ministry of Public Education, school district, decree, circular, trustee.

Дослідження різноманітних питань розвитку освіти України XIX ст. неможливе без використання джерел минулої епохи: документів, спогадів, мемуарів, листів тощо. Для вивчення функціонування Київського навчального округу найбільш актуальними у цьому плані $\epsilon$ нормативно-правові документи, що визначали його устрій. До них відносяться укази імператора, розпорядження міністра народної освіти, циркуляри попечителя Київського навчального округу. У пропонованій статті головна увага зосереджена на перших двох, як таких, що формували засадничі принципи існування округу, визначали головні критерії його розвитку. Задля легального розгляду зазначених документів аналізуються два перші роки функціонування Київського навчальногоого округу - 1833 і 1834.

Формування освітньої політики Російської імперії здійснювалося на найвищому, відомчому і місцевому рівнях державного управління. До першого входили імператор, його канцелярія, Державна Рада, Сенат, Комітет Міністрів. На другому рівні головна роль належала Міністерству народної освіти, яке взаємодіяло 3 іншими відомствами, що формували загальнодержавну освітню політику та брали участь у іiі реалізації. Розділення управління освітою між кількома державними органами призводило до конкуренції і викликало прагнення міністерства зосередити освітні справи у своїх руках [1, с. 475-476]. До відомчого рівня входили структурні підрозділи Міністерства народної освіти: міністр, товариш міністра, Рада міністра, канцелярія, департамент народної освіти, Вчений Комітет, редакція «Журнала министерства народного просвещения», чиновники з особливих доручень та інші.

На місцевому рівні державна освітня політика впроваджувалася за допомогою попечителя навчального округу. У своїй діяльності він мав підтримку попечителя, ради при попечителі, канцелярії, ректорів і директорів середньої і вищої шкіл округу, дирекції та інспекції народних училищ, попечительських й педагогічних рад, господарських комітетів шкіл, комітетів земств 3 освіти [2, с. 142-143].

Головними документами, які регулювали діяльність попечителя навчального округу, були імператорські укази, або «высочайшие повеления» та циркулярні розпорядження Міністерства народної освіти. За період 1833-1834 років набули чинності кілька указів імператора та циркулярів управляючого міністерством, що стосувалися різноманітних аспектів управління навчальними округами загалом і Київським навчальним округом зокрема. Друкувалися зазначені документи у відомчому органі Міністерства народної освіти «Журнал министерства народного просвещения» (далі - «Журнал»), що дозволяє проаналізувати їх у хронологічній 
послідовності. Протягом 1833 р. Міністерство народної освіти видало чотири розпорядження щодо управління навчальними округами (з них два стосувалися безпосередньо Київського навчального округу). За той же період з'явилися два «высочайшие повеления», пов'язані 3 Київським навчальним округом, які імператор затверджував на підставі подань управляючого Міністерством народної освіти до Комітету Міністрів.

Спочатку розпорядженням управляючого міністерством від 3 і 6 травня 1833 p. попечителям надавалося право дозволяти університетам і навчальним закладам підлеглих округів «производить сверхштатные издержки, не превышающие 500 рублей, из хозяйственных сумм сих заведений» [3, с. 211], але не інакше, як у випадках особливих потреб 3 «надлежащею осторожностью и бережливостью» [3, с. 211]. Циркуляр мав на меті уникнення зайвого i досить часто безкорисного листування між попечителями i міністерством у розв'язанні дріб'язкових питань місцевого значення.

Невдовзі 23 травня 1833 р. набув чинності циркуляр про введення у повітових училищах Чернігівської губернії викладання предметів згідно зі статутом 1828 р. Цим циркуляром управляючий Міністерством народної освіти підтримав подання попечителя Київського навчального округу і надав останньому дозвіл «сделать распоряжение о введении в Уездные Училища Черниговской губернии преподавания предметов по Уставу Учебных заведений 8 декабря 1828 года, с прекращением преподавания излишних против оного предметов, положенных в Уставе 1804 года» [3, c. LIX-LX].

27 травня 1833 року управляючий міністерством видав циркулярне розпорядження для попечителів та їхніх помічників під назвою «Статьи, на которые... Гг. Попечители и Помощники Попечителей должны обращать особенное внимание при обозрении Учебных Округов» [3, c. LX-LXYI]. До розпорядження увійшли три блоки питань: «по части нравственной», «по части учебной» і «по части хозяйственной и полицейской». Відповідно до першого блоку належало звертати увагу: «1) на нравственное направление преподаваний, наблюдая строго, чтобы в уроках Профессоров и Учителей не укрывалось ничего, колеблющего или ослабляющего учение Православной веры; ...2) чтобы между лицами, принадлежащими каждому учебному заведенню, при надлежащем повиновении начальству водворялись мир и согласие; ...3) ... чтобы в поведении и поступках начальствующих и преподавателей в учебных заведеннях не было чего-либо соблазнительного...; 4) чтобы наблюдались все нужные меры осторожности к предохранению воспитанников от пороков дурных связей, неприличного обращения и знакомства...» [3, с. LXI-LXII].

Щодо навчального процесу, то циркуляр зобов'язував особливо пильно оглядати облаштування порядку навчання, системність, послідовність і зміст навчальних предметів, здібності викладачів, рівень викладання російської мови і словесності, рівень патріотичного виховання, поклоніння престолу. Лише останнім пунктом стояла вимога перевіряти стан матеріально-технічного забезпечення. «В достоточном ли количестве при учебных заведеннях состоят учебные пособия, как-то: книги, глобусы, ландкарти, атласы, библиотеки, собрание физических и других орудий и проч.» [3, с. LXII].

До третього розділу входили питання «по части хозяйственной и полицейской», які поділялися на п'ять груп. Перша група стосувалося огляду навчальних приміщень. Попечителів зобов'язували перевіряти надійність будівель, де розміщені навчальні заклади; необхідність проведення у них ремонту; достатність виділеного фінансування; задовільність ремонтів попередніх років; погодження із затвердженими кресленнями і кошторисами; зручність розташування будівель з огляду на їх призначення.

Другу групу складали питання, пов’язані з бухгалтерією закладів освіти: законність витрат, наявність залишків фінансових сум, збереження порядку у веденні справ, шнурових книг і звітів. Попечителі мали також перевіряти стан капіталів шкіл, училищ і гімназій: «Ежели Учебные заведения имеют собственность в капиталах или в недвижимом имении, то приносят ли имущества сии соразмерный доход, и обеспечены ли они от упадка, расстройства и потери?» [3, с. LXШ].

Третя група питань стосувалася господарської частини: «добротны ли запасы, приобретаемые Учебними заведеннями из частных рук? За выгодную ли для казны цену они приобретаются, и соблюдается ли благоразумная бережливость в расходовании их?» [3, c. LXW]. Четверта група мала на меті з'ясувати санітарно-гігієнічний стан середовища: чистота 
приміщень, одягу, їжі учнів, провітрюваність класів, вживання заходів для охорони здоров'я, а остання, п'ята, група питань з'ясовувала протипожежний стан навчальних корпусів і рівень готовності до ліквідації можливої пожежі.

Окремо в циркулярі від 27 травня 1833 р. виокремлювався розділ про огляд приватних закладів. Причому особливо рекомендувалося перевіряти таке:

«1) Получили ли содержатели пансионов законное на то право?

2) Пользуются ли они и избранные ими наставники добрим именем, и не употребляют ли во зло доверенности родителей?

3) Учителя пансионов имеют ли свидетельства, установленные Височайшим Указом 1757 года?

4) Не упускается ли из виду преподавание наук на русском языке?

5) Не употребляются ли руководством в обучении юношества такие учебные книги, которие не утверждены учебным начальством?» [3, с. LXIV].

Останній пункт статей для попечителів та їхніх помічників щодо огляду підлеглих їм округів був пов'язаний із наглядом за університетом. Головна ідея полягала в обов'язкових іспитах для гімназистів під час вступу до університету, не звертаючи уваги на атестат, як безумовне і достатне свідчення їхніх здібностей. Управляючий міністерством вимагав більш суворого іспиту як для гімназистів, так i для випускників університету. У циркулярі зазначалося: «Не число студентов, а уравнительное между ими приготовление к высшему образованию и стройное развитие умственных сил, обещают полезных граждан и хороших учителей» $[3$, c. LXV]. Особливо попечителю наказувалося слідкувати за дисципліною серед «казенных» і «своєкоштних» студентів та не допускати будь-яких ії порушень. Якщо ж порушення все-таки траплялися, то керівництво мало «принимать неослабно к водворению сей меры законом предписанные» [3, c. LXVI].

За розпорядженнями міністра відбувалися звільнення та призначення чиновників в округах. По Київському навчальному округу відповідним циркуляром міністра восени 1833 р. були звільнені почесні доглядачі Зіньківського і Козелецького повітових училищ і призначені на службу професор фізики до Ліцею кн. Безбородька, директор училищ Волинської губернії, два чиновники з особливих доручень при попечителі Київського навчального округу, а також почесні доглядачі Махнівського, Стародубського, Погарського і Зіньківського повітових училищ [4, с. CLIX].

Окрім зазначених міністерських розпоряджень у 1833 р. з'явилися два імператорські укази, безпосередньо пов'язані з Київським учбовим округом. У першому з них від 6 червня 1833 р. імператор затвердив положення Комітету Міністрів згідно 3 поданням управляючого міністерством народної освіти про призначення пенсій училищним чиновником Волинської та Подільської дирекції і Волинського ліцею за статутом навчальних закладів 1828 р. За цим положенням префекту Волинського ліцею Княгницькому призначалося після звільнення за більш ніж 20-річну службу пенсія у розмірі по 300 р. сріблом на рік та дозволялося «назначать впредь чиновникам гимназий и уездных училищ Волынской губернии пенсии на основании того же устава [1828 р. - Авт.], с распространением сего и на Волынский лицей до издания особого устава для сего заведення» [3, с. XX-XXI].

Іншим указом від 5 вересня 1833 р. імператор призначив двох чиновників з особливих доручень при попечителі Київського навчального округу для посилення канцелярії останнього. Відповідна пропозиція надійшла від управляючого міністерством народної освіти до Комітету Міністрів, положення якого і затвердив імператор. Пізніше 8 жовтня міністром на нововведені посади чиновників були призначені вчитель Київської гімназії Петров і повірений колишньої фундушевої комісії колезький секретар Козачинський [4, с. CLIX]. Згідно з указом кожному 3 них призначалася платня по 2500 руб. із сум загального едукаційного фундушу. Одночасно указ визначав: «до утверждения и приведения в действо Устава и Штата Лицея в Киеве... на содержание Попечительской Канцелярии... производить по 4500 руб. в год из общего училищного капитала» [4, c. LXXXI-LXXXII].

У 1834 р. кількість імператорських указів щодо різноманітних аспектів функціонування навчальних округів i, зокрема, Київського значно переважала відповідні міністерські розпорядження. Останніх, опублікованих в «Журнале», було лише два: від 15 лютою і 28 червня 1834 року. Перший був пов'язаний із поступовим запровадженням у Київському 
навчальному окрузі правил, єдиних для навчальних закладів нижчої і середньої ланки інших округів та реорганізацією училищ Харківського і Київського навчальних округів за статутом 1828 р. У зв'язку 3 такими нововведеннями управляючий міністерством запропонував попечителям «произвести сие не вдруг», а поступово, враховуючи такі правила: 1) з учителів і училищних чиновників залишити лише обдаровані, усіх інших із слабкими знаннями i сумнівної поведінки звільнити з посад, попередньо повідомити їх про звільнення; 2) після введення нових штатів не доручати одному вчителю викладання у двох класах та не клопотатися про призначення йому подвійної платні, що практикувалося до того часу з огляду на невисокі заробітки вчителів; 3) за неможливості швидкого заміщення вакантних посад директора, інспектора і доглядача, доручати виконання цих обов'язків згідно зі статутом, «с производством за сие содержания по вакантному месту на основании высочайше утвержденного 3 мая 1832 года Положения Комитета Министров: о чем и входить каждый раз с представлением Министерству» [5, с. ХСУШ-ХСІХ]; 4) у тих гімназіях, де 3 вільновідвідуючих учнів збиралася плата, не припиняти ії збору, а продовжувати на попередній підставі; 5) до запровадження окремих приходських училищ, не розформовувати їхніх замінників на той час - початкові класи. необхідні для підготовки до здобуття освіти в повітових училищах [5, с. XCIX].

Окремо управляючий запропонував попечителю Київського навчального округу, щоб суми, які відпускалися «Приказами Общественного Призрения Городскими Думами, употреблять, со времени введения новых Штатов, преимущественно на поддержание Училищных зданий и на другие нужные собственно для училищ предмети» [5, c. XCIX].

Процедура введення єдиного статуту навчальних закладів у Київському навчальному окрузі завершилася указом імператора Сенату від 5 липня 1834 р. про поширення «Устава учебных заведений 1828 года» на Білоруський і Київський навчальні округи. Оскільки «учебные заведения губерний, составлявших прежде Виленский Учебный Округ, а ныне принадлежащих к Белорусскому и Киевскому, не имели для руководства своего твердых и постоянных правил, а в последствии получили устройство, основанное на началах Устава 8 декабря 1828 года» [6, с. ХХХУП-ХХХУШ], наказувалося ввести відповідальний статут у гімназії та училища губерній: Волинської, Подільської, Київської, Віденської, Гродненської, Мінської та Білостоцької області.

Інше міністерське розпорядження в 1834 році для керівництва навчальними округами й управліннями було пов'язане з упорядкуванням системи звітності. 3 цією метою у Міністерстві народної освіти підготували циркуляр від 28 червня 1834 р. «О сроке предоставления годовых отчетов». Згідно з імператорським повелінням у державі змінювалися терміни подання річних звітів: «Годовые отчеты по Министерствам, вместо марта месяца, были представляемы в Комитет [Министров. - Авт.] не позже мая» [7, с. ХІІ-ХІІІ] Міністр народної освіти відповідно до указу продовжив термін, призначений для подання звітів у міністерство із навчальних округів і управлінь. За міністерським розпорядженням попечителі мали складати річні звіти про діяльність округу та стан навчальних закладів 31 січня. Для уніфікації річних звітів циркуляр зобов'язував попечителів «держаться во всей точности тех форм, какие разосланы при циркулярном предложении от 19 июня прошлого года для Университетов и Лицеев, для Учебных округов вообще и для каждой дирекции в частности, и от 16 сентября для Ученых Обществ» [7, с. XIII]. До міністерства річні звіти мали надходити «вместо 1 декабря, к 15 числу февраля» [7, с. XIV]. Виняток встановлювався лише для Сибірської і Закавказької дирекції, для яких цей термін продовжувався до 15 березня.

Імператорські укази, підписані в 1834 році і опубліковані в «Журнале», мали безпосереднє відношення до функціонування Київського навчального округу загалом і окремих навчальних закладів округу, зокрема. Укази імператора з'являлися після подання управляючим Міністерством народної освіти до Комітету Міністрів відповідних справ. Останній на їхній підставі розробляв положення, згідно з яким з'являлося «высочайшее повеление». Таким указом від 13 лютого 1834 року імператор дозволив після реорганізації Київської гімназії за статутом 8 грудня 1828 р. «иметь при оной Законоучителя Римскокатолического Исповедания с производством ему жалованья наравне с Законоучитслями Грекороссийского Исповедания, по тысяче рублей ассигнациями в год из Государственного казначейства» [5, с. XX]. 
Уже за кілька днів 20 лютого 1834 р. після розгляду Комітетом Міністрів імператор затвердив положення «О распостранении в 3-х Дирекциях Киевского округа на воспитанников Гимназий и Благородных пансионов прав, дарованных Положением 14 ноября 1833 г. Воспитанникам таковых же заведений в западных Дирекциях Белорусского Округа» $[5, \mathrm{c}$. XX$\mathrm{XXI]}$. Згідно з цим указом права, які отримували вихованці гімназій та існуючих при них пансіонів, що працювали при них у Віленській, Гродненській, Мінській губерніях та Білостоцькій області, поширювалися на вихованців відповідних закладів у Київській, Волинській і Подільській губерніях, що входили до Київського навчального округу.

Затвердженню імператором підлягали і справи, що могли розвязуватися на рівні Міністерства народної освіти. Так, наприклад справа про зміну місця розташування навчального закладу. За поданням попечителя Київського навчального округу міністр народної освіти подав на розгляд Комітету Міністрів, для отримання імператорського дозволу, записку, у якій пропонувалося: «Луцкую Гимназию, по тесноте помещения оной, перевести временно в Клевань, до открытия возможности устроить ее в одном из близлежащих к Луцку уездных городов Волынской Губернии, а Клеванское Уездное Училище поместить в Луцке» [8, c. CXXXУ_CXXXVI]. Згідно з положенням Комітету Міністрів імператор 1 травня 1834 р. дозволив необхідні переміщення. Іншим указом від 19 травня того ж року він затвердив подані міністром народної освіти «рисунки для шитья на мундирах Чиновников Киевского и Одесского Учебного Округов» [8, с. СХХХУІІ].

П'ятим червня 1834 року датовані ще два «высотайшие повеления'» імператора, пов'язані 3 Київським навчальним округом. Перший указ стосувався відкритого в Києві на Подолі повітового училища. Воно не мало власної будівлі, яку потрібно було або будувати, або купувати. Оскільки будівництво вимагало значних коштів і особливо часу, міністр народної освіти увійшов до Комітету Міністрів 3 поданням «об употреблении на покупаемый у Губернского Секретаря Доливы-Блотницкого дом для открытого в Киеве на Подоле Уездного Училища 35000 и исчисленных на исправление оного 2235 р. 30 к. ассигнациями» [7, с. IV]. Справу розв'язував імператор, оскільки гроші на купівлю пропонувалося взяти «заимообразно из суммьі 209508 руб. сереб., назначенной на возведение зданий Оршинского Лицея и обращенной Высочайшим Указом 28 февраля сего [1834. - Авт.] года на постройку зданий и другие потребности Университета Св. Владимира» [7, с. IV]. Подання міністра і рішення 3 цього питання Комітету Міністрів були 5 червня «удостоены высочайшего утверждения». Витрати мали покриватися за рахунок Державного Казначейства, а в подальшому вносилися до кошторису витрат Міністерства народної освіти на той рік, у якому «по дальнейшим соображениям предусмотрена будет действительная в оной надобность для настоящей цели ее предназначенная» [7, с. V].

Інший імператорський указ від 5 червня 1834 року «Об определении особых Архитекторов при Учебных Округах» був ініційований попечителем Казанського навчального округу. Він подав на розгляд міністра доповідну записку про необхідність архітектора для підлеглого йому округу. Міністр погодився 3 думкою попечителя i, беручи до уваги, що подібна потреба в особливих архітекторах може з'явитися і в інших навчальних округах, звернувся до Комітету Міністрів 3 поданням, де пропонувалося: «Высочайше утвержденное в 19 день декабря 1833 года Положение Комитета Министров об определении особого Архитектора при Московском Учебном Округе, распостранить на Казанский Округ и на другие, по мере представляемой в том местным Начальством надобности [7, с. V]. У майбутньому посаду архітектора введено до штату і Київського навчального округу.

Аналіз вищенаведених документів дозволяє зробити узагальнення щодо початкового етапу функціонування Київського навчального округу. У системі освіти мала місце складна і тривала процедура прийняття рішень. Громіздка бюрократична тяганина унеможливлювала швидке реагування Міністерства народної освіти на потреби викладачів, учнів і загалом системи освіти. Надмірна централізованість не дозволяла також попечителю виявити ініціативу і змушувала більше часу витрачати на «розв'язання» різноманітних рішень, а не слідкувати за навчальним процесом у підлеглому окрузі. 3 іншого боку, міністерство вимагало від попечителя повного й постійного контролю за навчанням і навіть повсякденним життям вихованців гімназій, училищ, пансіонів. Особливо непокоїли чиновників «крамольні» думки викладачів та їхніх помічників, про що красномовно свідчать циркуляри та розпорядження. 
Безпосередньо в Київському навчальному окрузі протягом розглянутого дворіччя відбувалося поступове введення правил, єдиних для інших округів імперії, проходив процес нівелювання відмінностей між навчальними закладами Київського округу порівняно з іншими російськими округами. Ці документи важливі дія істориків, оскільки вони характеризують політику, яку проводила Російська імперія на українських землях після придушення польського повстання 1830-1831 рр., коли більшість польськомовних навчальних закладів закрили, їх відкриття супроводжувалося введенням жорсткіших правил контролю та нагляду. Лібералізм періоду візитаторства Ф. Чацького та панівного становища у регіоні польської культури змінився на виховну систему, девізом якої була відома формула С. Уварова «самодержавство, православ'я, народ». Загалом Київський навчальний округ поступово входив до єдиної державної системи освіти, зазначені укази та циркуляри мали всіляко сприяти такому процесу.

\section{Література}

1. Рождественский С. В. Исторический обзор деятельности Министерства Народного Просвещения / С. В. Рождественский (1802-1902). - СПб., 1902. 2. Шевелев А. Н. Школа. Государство. Общество. Очерки социально-политической истории общего школьного образования в России второй половины XIX века / А. Н. Шевелев. - СПб., 2001. 3. Журнал министерства народного просвещения. 1834. -№1, январь. 4. Журнал министерства народного просвещения. - 1834. - № 2, февраль. 5. Журнал министерства народного просвещения. - 1834. - № 4, апрель. 6. Журнал министерства народного просвещения. - 1834. - №8, август. 7. Журнал министерства народного просвещения. 1834. - № 7, июль. 8. Журнал министерства народного просвещения. - 1834. - №6, июнь.

\section{ТЛУМАЧЕННЯ ДЕФІНЦІЇ «КРИТИЧНЕ МИСЛЕННЯ»: ІСТОРИЧНИЙ ЕКСКУРС}

Краснолуцький К. К. Тлумачення дефініції «критичне мислення»: історичний екскурс.

У статті аналізується поняття «критичне мислення». Розглядаються історія розвитку й еволюція дослідження поняття «критичне мислення», основні етапи розвитку критичного мислення й оцінювання його рівнів розвитку в науковій літературі. Здійснено аналіз дефініції на сучасному етапі: 1) психологічна готовність розглядати вдумливо проблеми і питання, що входять до спектру власного життєвого досвіду; 2) знання методів логічного дослідження й аргументації; 3) наявність певних навичок у застосуванні цих методів.

Ключові слова: мислення, критичне мислення, творче мислення, етапи розвитку критичного мислення.

Краснолуцкий К. К. Толкование дефиниции «критическое мышление»: исторический экскурс.

В статье анализируется понятие «критическое мышление». Рассматривается история развития и эволюция исследования понятия «критическое мышление», основные этапы развития критического мышления и оценки его уровней развития в научной литературе. Подан анализ дифиниции на современном этапе: 1) психологическая готовность рассматривать вдумчиво проблемы и вопросы, которые входять в спектр собственного жизненного опыта; 2) знание меодов логического исследования и аргументации; 3) наявность определенных навыков в применении этих методов.

Ключевые слова: мышление, критическое мышление, творческое мышление, этапы развития критического мышления.

Krosnolutskiy K. K. Interpretation definitions of «critical thinking»: historical background.

The article analyzes the concept «critical thinking». The history of the development and evolution of the study of "critical thinking», the main stages in the development of critical thinking and evaluation of its development levels are considered in the scientific literature. At this stage there was made the analysis of definitions: 1) psychological readiness to consider carefully the issues and questions that are part of the own life experience, 2) knowledge of the methods of research and logical reasoning 3 ) the presence of certain skills in these methods application.

Key words: thinking, critical thinking, creative thinking, critical thinking development stages. 